\title{
Exploratory study on maturation and competition level in young karate practitioners
}

\author{
Marco BRANCO*1,2,4,5 (D), António VENCESBRIT01,2,3,5 (D), Ana Paula SEABRA 1,2 (D), Cristiana \\ MERCE $^{1,2,3}$ (D), Mário A. RODRIGUES-FERREIRA ${ }^{1,2,3}$ (D), Vitor MILHEIR0 ${ }^{1,2}$ (D), \& David \\ CATELA $^{1,2,3}$
}

${ }^{1}$ Sport Sciences School of Rio Maior, Polytechnic Institute of Santarém, Rio Maior (Portugal)

${ }^{2}$ Research Unit of Polytechnic Institute of Santarém (UIIPS) (Portugal)

${ }^{3}$ Life Quality Research Centre - CIEQV (Portugal)

${ }^{4}$ Biomechanics and Functional Morphology Laboratory, Interdisciplinary Centre for the Study of Human Performance-University of Lisbon (CIPER-UL) (Portugal)

5 International Martial Arts and Combat Sports Scientific Society (IMACSSS) (Poland)

Received: 23/01/2019; Accepted: 18/03/2019; Published: 20/03/2019.

\begin{abstract}
Paring children improve the chance for success and reduce injury in sport. Despite the maturity differences between children, chronological age remains the main criterion to equalize competition levels, but with limited efficiency. However, in Karate, weight is also considered. We went to investigate the association between chronological age and maturational indicators and find simple models to put on reflection new ways to assess the maturity. Data were collected in 54 young Karate practitioners (age: $12.67 \pm 2.49$ years, experience: $4.99 \pm 2.44$ years, height: $150.45 \pm 15.25 \mathrm{~cm}$, weight: $43.09 \pm 14,17 \mathrm{~kg}, 20$ girls). Age correlated significantly with self-observation of sexual maturation (rho = $0.838 ; p$ $<0.01$ ), and it was possible to find simple regression models that have a moderate explanation in maturation, using only simple measurable variables such as the height, weight and arm circumference. These results should lead the competent entities to reflect on the way of pairing of the athletes in the competitions, in a fair way in terms of maturation.

Keywords: Sports competition; maturation; Karate; martial arts; combat sports; kumite.
\end{abstract}

\section{Estudio exploratorio sobre maduración y nivel de competición en jóvenes practicantes de karate \\ Resumen}

El establecimiento de categorías en competiciones de jóvenes mejora las posibilidades de éxito y reduce las lesiones en el deporte. A pesar de que existen diferencias de maduración, la edad cronológica sigue siendo el criterio principal para igualar los niveles de competición, lo cual tiene una eficiencia limitada. En karate, el peso también se utiliza para agrupar atletas. Hemos investigado si existe asociación entre la edad cronológica y los indicadores de maduración y si es posible encontrar modelos sencillos que permitan plantear nuevas formas para evaluarla. Se recogieron datos de 54 jóvenes practicantes de karate (edad: 12,67 $\pm 2,49$ años; experiencia: 4,99 $\pm 2,44$ años, altura: $150,45 \pm 15,25 \mathrm{~cm}$, peso: $43,09 \pm 14,17 \mathrm{~kg}, 20$ niñas). La edad se correlacionó significativamente con la auto-observación de la maduración sexual (rho $=0,838, p<$ 0,01). Se encontraron modelos de regresión sencillos, utilizando variables como la altura, peso y perímetro del brazo, que explican moderadamente la maduración. Estos resultados deben hacer reflexionar a las entidades competentes sobre cómo agrupar a los atletas en las competiciones de manera justa en términos de maduración.

\section{Estudo exploratório sobre maturação e nível de competição em jovens praticantes de karatê}

\section{Resumo}

Emparelhar crianças propicia sucesso e reduz lesões no desporto. Apesar das diferenças de maturação entre crianças, a idade cronológica mantém-se o principal critério para equalizar os níveis de competição, mas com uma eficiência limitada. No entanto, no karaté, o peso também é considerado. Fomos verificar se existe associação entre a idade cronológica e os indicadores maturacionais e, encontrar modelos simples que permitam colocar em reflexão novas formas de avaliação da maturação. Foram recolhidos dados em 54 jovens praticantes de karaté (idade: 12,67 $\pm 2,49$ anos; experiência: 4,99 $\pm 2,44$ anos; altura: $150,45 \pm 15,25 \mathrm{~cm}$; peso: $43,09 \pm 14,17 \mathrm{~kg}, 20$ raparigas). A idade correlacionou-se significativamente com auto-observação da maturação sexual (rho $=0,838 ; p<0,01$ ), e foi possível encontrar modelos de regressão simples que têm uma explicação moderada na maturação, apenas utilizando variáveis de medição simples, tal como a altura, o peso e o perímetro do braço. Estes resultados devem levar as entidades competentes a refletir acerca do modo de emparelhamento dos atletas nas competições de uma forma justa em termos de maturação.

*E-mail: marcobranco@esdrm.ipsantarem.pt 
Palabras clave: Competición deportiva; maduración; karate; artes marciales; deportes de combate; kumite.
Palavras-chave: Competição desportiva; maturação; karaté; artes marciais; desportos de combate; kumite.

\section{Introduction}

Paring children lead to success and reduces injuries in sport (Malina \& Beunen, 1996). Despite the differences in maturation among children, chronological age remains the main criterion for equalizing the competition levels, but with limited efficiency (Malina, 2000). These differences in maturation among athletes or differences between chronological and biological age have been studied since the beginning of the $20^{\text {th }}$ century (e.g., Crampton, 1908), and have pointed out that maturational status had significant influences in physical fitness (Anderson \& Ward, 2002; Backous, Farrow, \& Friedl, 1990; Towlson, Cobley, Parkin, \& Lovell, 2018), performance (Pieter, 2012), and body dimensions (Backous et al., 1990).

Regarding competition in pre- and pubertal ages, this issue cannot be overlooked since the ages in which these differences most manifest, correspond precisely to the moment when factors such as abandonment, talent selection or sport specialization take place. In fact, Gabbett (2015) shows that there is a relationship between physical fitness, the playing level attained, some biomechanical variables, the anthropometric data, and the skill qualities, with the selection in team sports. Towlson et al. (2018) advertise that developmental trajectories are dynamic, asynchronous and staggered in young practitioners and should be avoided the (de)selection of these individuals due to factors that may be influenced by maturation.

In kumite (combat) competitions in karate beyond chronological age, the weight for pairing between competitors is also considered, with between two and six categories of weight for males and females (Federação Nacional de Karate - Portugal, 2017), for each level of competition. It is pertinent to clarify and alert the competent institutions to this problem, giving tools that allow the promotion of competitive equilibrium and healthy competition.

The objectives of this study were: 1) to verify if there is any association between chronological age and maturation indicators; 2 ) to find simple models that allow us to consider new ways of evaluating maturation focused on competition.

\section{Methods}

\subsection{Sample}

Data were collected from 54 youths, 20 girls and 34 boys, karate practitioners with ages between 7 and 16 years. Considering the levels of competition, 14 children belonged to the infantes (79 years), 7 to the initiates (10-11 years), 18 to juveniles (12-13 years), 14 to cadets (14-15 years) and 1 to juniors (16 years). The characterization of Table 1. Sample characterization.

\begin{tabular}{lcccc}
\hline Variables & Min. & Max. & $\boldsymbol{M}$ & $\boldsymbol{S D}$ \\
\hline Age & 7 & 16 & 11.76 & 2.49 \\
Weight & 21.40 & 74.60 & 43.09 & 14.17 \\
Height & 120.00 & 178.45 & 150.45 & 15.25 \\
Years of practice & 1 & 13 & 5.05 & 2.36 \\
\hline
\end{tabular}

the sample can be verified in Table 1.

The sample was recruited in Karate clubs and associations of the central region of Portugal. Before the data collection, the study was explained to the parents and to the children and was obtained assent from them (Winter \& Cobb, 2008). The study was carried out in accordance with the Helsinki Declaration and was approved by the Ethics Committee of the Research Unit of the Polytechnic Institute of Santarém. The collections were carried out between January and March of 2018, in the Research Laboratory in Sport Sciences School of Rio Maior

\subsection{Procedures and protocol}

The collections began by filling in the personal and parental data, by the general and specific history in Karate practice, namely the number of hours and weekly frequency of practice, years of practice and graduation level. Then was collected the anthropometric data as weight, height, percentage of fat mass (by bioimpedance), bicipital skinfold, tricipital skinfold, subscapular 
skinfold, suprailiac skinfold and arm circumference (flexed and tensed) (Figure 1). During the collections the children were accompanied by their parents or coaches.

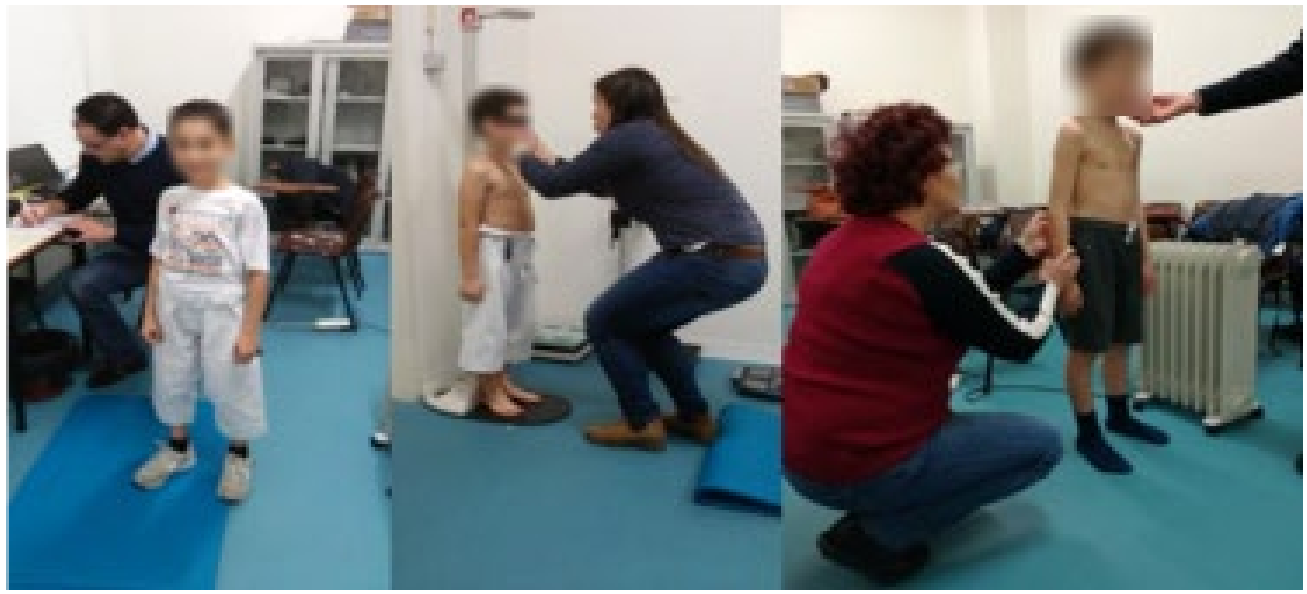

Figure 1. Collection of children anthropometric data.

The anthropometric data was collected according to the International Society for the Advancement of Kinanthropometry (ISAK) protocol (Stewart, Marfell-Jones, Olds, \& Ridder, 2011), and the measurements were made by certified researchers. The children were asked, with their parents and / or coaches help, to indicate on their own form the evaluation of the biological maturation based on the secondary sexual characteristic (Baxter-Jones, Eisenmann, \& Sherar, 2005), through stages of development of pubic hairiness (Baxter-Jones et al., 2005), with consultation of schematic illustrations and descriptive criteria (adapted from, Malina, Bouchard, \& Bar-Or, 2004).

The collected data were subsequently treated in order to obtain the body mass index (BMI), corrected arm circumference, percentage of body fat mass (Lohman, Roche, \& Martorell, 1988), predicted adult height (Khamis \& Roche, 1994). Through predicted adult height, it was calculated the relative height achieved at the moment of measurements.

To evaluate the maturational state of the athletes, the difference between their relative height and the relative height of reference for the age were calculated, and then evaluated their maturational state as "Maturational Delay", "Normal Maturacional State" or "Maturational Advancement" (Fragoso \& Vieira, 2011; Roche, Tyleshevski, \& Rogers, 1983; Roche, Wainer, \& Thissen, 1975).

\subsection{Statistical treatment}

The normality of the distribution was tested for all the variables under study, which was not assumed for all. To verify if there were differences between genders, the $t$-student test and the Mann-Whitney $U$-test were used. To verify the association between the variables under study, the rho-Spearman test was used, using linear regression to find the best variables that predict maturation levels. In all tests the accepted level of significance was $p<0.05$.

\section{Results}

Descriptive statistics can be found in Table 2. For the variables under study, only the percentage of body Fat Mass $(t=3.387, p<0.01)$ and tricipital skinfold $(U=197.000, p<0.01)$ were significantly higher in girls and the predicted adult height $(t=-6.446, p<0.01)$ were significantly higher in boys.

After performing the association between the decimal age and the self-reported biologic maturational stage (Tanner, 1962), it was found a strong association between them (rho $=0.838, p$ $<0.01$ ). Figure 2 shows the distribution of biological maturational stage per competition level, for boys and girls. Regarding the several competition levels, it is visible that the lower biological stages 
were reported manly in boys, and the girls register a higher frequency of the advanced levels of biological maturation in juveniles. These results were expected due to the maturational advance that girls have during adolescence.

Table 2. Descriptive statistics of the variables under study.

\begin{tabular}{lccc}
\hline Variables & $\begin{array}{c}\text { Sample } \\
\boldsymbol{M} \pm \boldsymbol{S D}\end{array}$ & $\begin{array}{c}\text { Girls } \\
\boldsymbol{M} \pm \boldsymbol{S D}\end{array}$ & $\begin{array}{c}\text { Boys } \\
\boldsymbol{M} \pm \boldsymbol{S D}\end{array}$ \\
\hline Age & $11.76 \pm 2.49$ & $11.80 \pm 2.55$ & $11.74 \pm 2.49$ \\
Practice Years & $5.05 \pm 2.36$ & $4.75 \pm 1.92$ & $5.22 \pm 2.60$ \\
Maturation Stage & $3.02 \pm 1.49$ & $3.25 \pm 1.33$ & $2.88 \pm 1.57$ \\
Weight (Kg) & $43.09 \pm 14.17$ & $43.98 \pm 13.68$ & $42.57 \pm 14.63$ \\
Height (Cm) & $150.45 \pm 15.25$ & $151.10 \pm 13.09$ & $150.07 \pm 16.56$ \\
BMI & $18.48 \pm 3.11$ & $18.82 \pm 3.38$ & $18.28 \pm 2.98$ \\
Bicipital skinfold & $3.95 \pm 2.77$ & $3.96 \pm 2.50$ & $3.94 \pm 2.96$ \\
Tricipital skinfold & $10.25 \pm 4.43$ & $11.94 \pm 4.23$ & $9.26 \pm 4.30$ \\
Subscapular skinfold & $7.34 \pm 3.80$ & $8.04 \pm 4.08$ & $6.93 \pm 3.62$ \\
Suprailiac skinfold & $7.83 \pm 4.64$ & $7.79 \pm 4.13$ & $7.85 \pm 4.98$ \\
Arm Circumference & $22.75 \pm 4.06$ & $22.98 \pm 3.55$ & $22.61 \pm 4.38$ \\
Corrected Arm Circumference & $21.73 \pm 3.81$ & $21.79 \pm 3.24$ & $21.69 \pm 4.16$ \\
\% Fat Mass by skinfolds & $15.15 \pm 6.32$ & $18.62 \pm 5.67$ & $13.11 \pm 5.83$ \\
Predicted Adult height & $171.39 \pm 9.00$ & $161.59 \pm 5.64$ & $175.59 \pm 6.55$ \\
Relative Height & $87.53 \pm 9.38$ & $90.64 \pm 9.29$ & $86.20 \pm 9.26$ \\
\hline
\end{tabular}

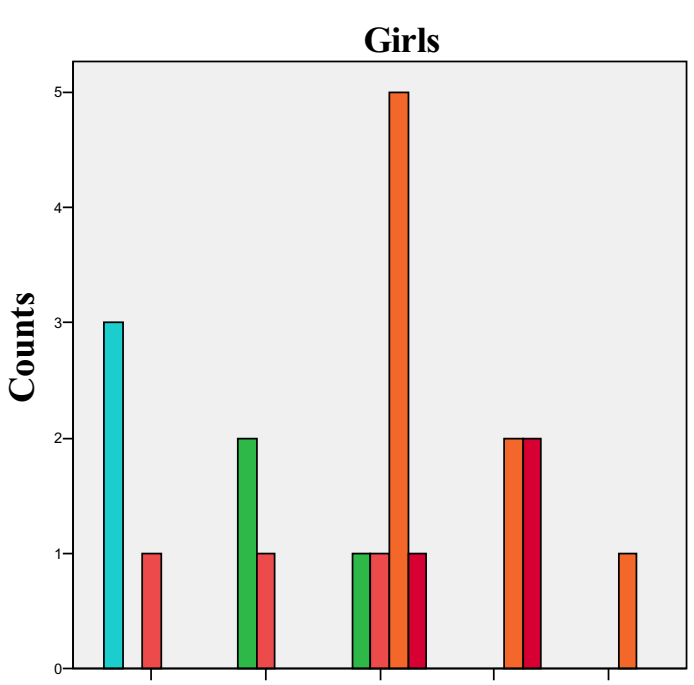

Infant Iniciates Juveniles Cadets Juniors

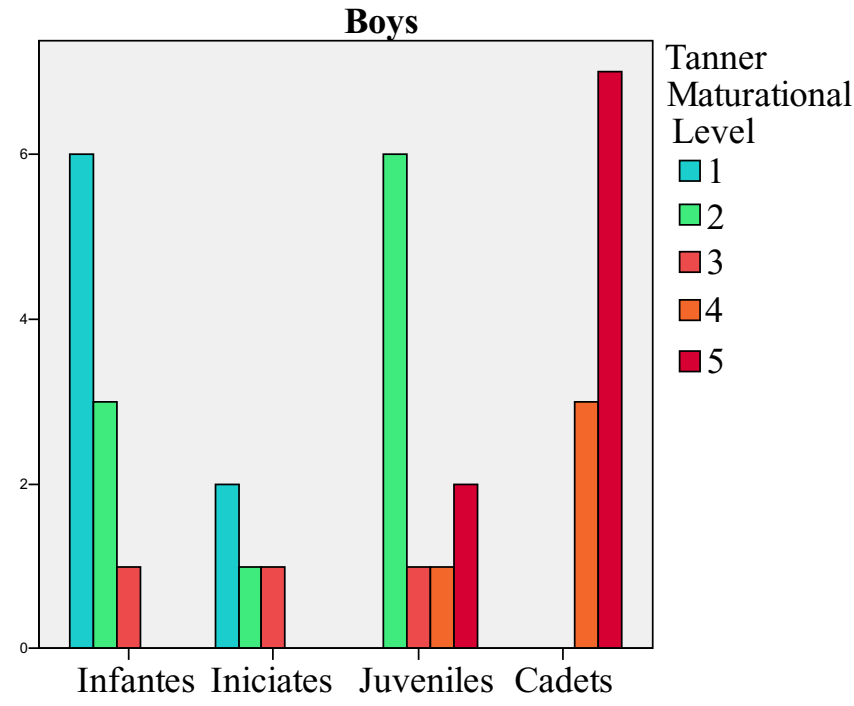

Boys

Competition Level

Figure 2. Number of cases of different stages of biological maturation by competition level and gender..

Based on calculations of predicted adult height, the evaluation of the maturation state (Table 3), presents only two children (3.7\%) with a maturation delay. Most of the evaluated children $(40.7 \%)$ had a normal maturation state and sixteen children $(29.6 \%)$ had an advanced maturation state

Table 3. Evaluation of the maturation state by competition level.

\begin{tabular}{|c|c|c|c|c|c|c|}
\hline & & Not evaluated & Maturational delay & $\begin{array}{c}\text { Normal } \\
\text { maturational state }\end{array}$ & $\begin{array}{l}\text { Maturational } \\
\text { advancement }\end{array}$ & Total \\
\hline \multirow{6}{*}{ 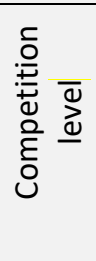 } & Infantes & 2 & 1 & 6 & 5 & 14 \\
\hline & Initiates & 2 & 1 & 2 & 2 & 7 \\
\hline & Juveniles & 4 & 0 & 8 & 6 & 18 \\
\hline & Cadets & 5 & 0 & 6 & 3 & 14 \\
\hline & Juniors & 1 & 0 & 0 & 0 & 1 \\
\hline & Total & 14 & 2 & 22 & 16 & 54 \\
\hline
\end{tabular}


In an attempt to verify if it is possible to have evidence of the biological maturation stage of the children through simple and non-invasive measurements, we found that for both sexes it was possible to find regression models with three of the variables under study. Thus, height (h), weight $(\mathrm{w})$ and arm circumference (ac) were used as can be seen below in Equation 1 and Equation 2.

Equation 1. Statistical regression equation to access maturation stage for females $\left(\mathrm{R}^{2}\right.$ adj $\left.=0.591\right)$.

Maturation Stage $=0.055 \times \mathrm{h}+0.007 \times \mathrm{w}+0.099 \times \mathrm{ac}-7.697$

Equation 2. Statistical regression equation to access maturation stage for males $\left(\mathrm{R}^{2}{ }_{\mathrm{adj}}=0.727\right)$.

Maturation Stage $=0.051 \times h+0.045 \times w-0.030 \times a c-6.019$

The explanation of the predictor variables in the maturational stage is $59.1 \%$ in the girls' model and $72.7 \%$ in the model of the boys.

\section{Discussion}

This study aims to analyze the association between chronological age and biological age and to explore different anthropometric parameters and body composition, verifying which can be indicators of maturation, with the particularity of being measured more easily. For the first goal, our results show a strong association between chronological age and the Tanner's self-reported maturation stage. This corroborates that it is in this age range that the greatest changes in maturation occur, which reveals the interest in continuing the study of the individuals that are in this phase of development.

In the body composition and anthropometric parameters, it was detected that the body fat mass and the tricipital skinfold were significant higher for girls and the predicted adult height was significant higher for boys. These results were expected and can be explained by the differences between boys and girls, considering the sexual dimorphism of the human species (Roberto, Elisabetta, \& Giovanni, 2001).

The question we want to explore is whether children belonging to the same category of competition have different maturations, which leads to an unbalanced confrontation, since athletes with higher maturation levels have greater physical skills (Anderson \& Ward, 2002; Backous et al., 1990; Pieter, 2012; Towlson et al., 2018), which in turn increases the chance of winning (Gabbett, 2015). Analyzing these evaluations by the category of competition, we found that there were several categories with maturational advanced athletes, showing that competitive equity may be at stake. It should be noted that the lowest competition categories were those in which more children presented a maturational advance for the chronological age they have, and it is also in these levels that it is important to show the Karate as a game and therefore when we should put two similar children face-to-face.

Other authors have attempted to verify whether there would be an easier way to group children in pubertal stages in order to create fair conditions without undermining the athletes' health. Dubnov-Raz, Mashiach-Arazi, Nouriel, Raz, and Constantini (2015), aims to study the relationship between height and weight in competitive karate fighters in the pediatric age range and to examine if height categories could be used as an alternative to weight categories. These authors found that dividing the young karate athletes by height categories significantly reduced the range of heights of competitors within category, and do not origin athletes compete against much heavier opponents. Also, seems to be a good way to reduce eating disorders in combat sports, in order to belong a specific weight category. In the same way, De la Fuente García (2018) studied whether height categories can be used as a healthier alternative to weight categories for official competition in taekwondo. This author found that young competitive athletes can be categorized by height in official competition, as a healthier and more equitable alternative to the current weight divisions. However, these studies, only focus the growth of children, and there is no information about their development. 
In our study, we tried to find simple regression models that allow us to consider new ways of evaluating maturation with a focus on competition, through easy and non-invasive measurements. Based on these models, height, weight and arm circumference were highlighted as predictors of the maturation stage, with the particularity of being easily measured and without requiring a large apparatus. The explanation of these models shows that for the female athletes the three variables have a prediction of $59.1 \%$ of the maturational stage, whereas for the male athletes there is a prediction of $72.7 \%$. The differences between the models can be explained by a greater diversity of maturational stages by body dimensions among girls, while boys with higher body dimensions also tend to have greater maturational stages, which makes the boy's model more able to predict maturity than girls. Thus, in addition to weight, we recommend measuring the height and the arm circumference as a way to equitably pair the athletes in the competitions. Although these models require further investigation, their use can be considered due to the ease of data collection. We recommend, however, that in future studies the sample should be increased by competition level.

\section{Conclussion}

Despite differences in maturation among children, chronological age remains the main criterion for equalizing levels of competition. Although it is the object of study over the years, maturation evaluation has never been effective as a form of pairing of athletes, possibly due to the complexity of measuring maturation. With this study, we verified the association between chronological age and maturation indicators. Besides that, it was possible to find simple regression models that have a moderate explanation of maturation, only using simple measurement variables, such as the height, weight and the arm circumference. These results should lead the competent entities to reflect on the pairing mode of the athletes in the competitions, in this case in Karate competitions.

\section{Acknowledgements}

The authors are grateful for the availability of athletes and coaches from: Associação AMICALE Karate; AKDS - Clube Atlético do Montijo; AKWK - Associação de Karaté-Do Wado-Kai.

\section{References}

Anderson, G. S., \& Ward, R. (2002). Classifying children for sports participation based upon anthropometric measurement. European Journal of Sport Science, 2(3), 1-13. doi: $10.1080 / 17461390200072301$

Backous, D. D., Farrow, J. A., \& Friedl, K. E. (1990). Assessment of Pubertal Maturity in Boys, Using Height and Grip Strength. Journal of Adolescent Health, 11(6), 497-500. doi: 10.1016/01970070(90)90109-F

Baxter-Jones, A. D. G., Eisenmann, J. C., \& Sherar, L. B. (2005). Controlling for maturation in pediatric exercise science. Pediatric Exercise Science, 17(1), 18-30. doi: 10.1123/pes.17.1.18

Crampton, C. W. (1908). Physiological Age-A Fundamental Principle. American Physical Education Review, 13(4), 214-227. doi: 10.1080/23267224.1908.10650080

De la Fuente García, A. (2018). Height categories as a healthier alternative to weight categories in taekwondo competition. Revista de Artes Marciales Asiáticas, 13(1), 53-60. doi: $10.18002 /$ rama.v13i1.5350

Dubnov-Raz, G., Mashiach-Arazi, Y., Nouriel, A., Raz, R., \& Constantini, N. W. (2015). Can height categories replace weight categories in striking martial arts competitions? A pilot study. Journal of Human Kinetics, 47, 91-98. doi: 10.1515/hukin-2015-0065

Federação Nacional de Karate - Portugal. (2017). Regulamento Geral de Provas. Lisboa, Portugal: Federação Nacional de Karate - Portugal.

Fragoso, M. I. C. J., \& Vieira, M. F. S. (2011). Cinantropometria: Curso Prático. Cruz Quebrada, Lisboa: Faculdade de Motricidade Humana.

Gabbett, T. J. (2015). Physical Qualities of Experts. In J. Baker \& D. Farrow (Eds.), Routledge Handbook of Sport Expertise (pp. 121-129). London \& New York: Routledge. 
Khamis, H. J., \& Roche, A. F. (1994). Predicting adult stature without using skeletal age: the KhamisRoche method. Pediatrics, 94(4 Pt 1), 504-507.

Lohman, T. G., Roche, A. F., \& Martorell, R. (1988). Anthropometric standardization reference manual. Champaign, IL: Human Kinetics Books.

Malina, R. M. (2000). Growth, maturation and performance. In Garret \& Kirkendall (Eds.), Exercise and Sport Science (pp. 425-445). Philadelphia: Williams \& Wilkins.

Malina, R. M., \& Beunen, G. (1996). Monitoring of growth and maturation. In Bar-Or, Commission, \& International Federation of Sports (Eds.), The Child and Adolescent Athlete (pp. 647-672). Oxford; Cambridge, Mass., USA; Champaign, Ill.: Blackwell Science.

Malina, R. M., Bouchard, C., \& Bar-Or, O. (2004). Growth, Maturation, and Physical Activity (2nd ed.). Champaign, Ill.: Human Kinetics Books.

Pieter, W. (2012). Talent Detection in Taekwondo Practitioners. Revista de Artes Marciales Asiáticas, 5(2), 77-96. doi: $10.18002 /$ rama.v5i2.112

Roberto, B., Elisabetta, M., \& Giovanni, F. (2001). Variation in sexual dimorphism in relation to physical activity. American Journal of Human Biology, 13(3), 341-348. doi: 10.1002/ajhb.1057

Roche, A. F., Tyleshevski, F., \& Rogers, E. (1983). Non-Invasive Measurements of Physical Maturity in Children. Research Quarterly for Exercise and Sport, 54(4), 364-371. doi: $10.1080 / 02701367.1983 .10605321$

Roche, A. F., Wainer, H., \& Thissen, D. (1975). Predicting adult stature for individuals. Monographs in Paediatrics, 3, 1-114.

Stewart, A., Marfell-Jones, M., Olds, T., \& Ridder, H. d. (2011). International Standards for Anthropometric Assessment. New Zealand: The International Society for the Advancement of Kinanthropometry.

Tanner, J. M. (1962). Growth at adolescence (2nd ed.). Oxford: Blackwell Scientific Publications.

Towlson, C., Cobley, S., Parkin, G., \& Lovell, R. (2018). When does the influence of maturation on anthropometric and physical fitness characteristics increase and subside? Scandinavian Journal of Medicine \& Science in Sports, 28(8), 1946-1955. doi: 10.1111/sms.13198

Winter, E. M., \& Cobb, M. (2008). Ethics in Paediatric Research: Principles and Processes. In N. Armstrong \& W. v. Mechelen (Eds.), Paediatric Exercise Science and Medicine (pp. 3-12). Oxford: Oxford University Press.

\section{Author's biographical data}

Marco Branco (Portugal) is a lecturer on the Sport Sciences School of Rio Maior, Polytechnic Institute of Santarém, Portugal, in the areas of Biomechanics and Motor Control and Learning. PhD in Human Kinetics, specialization in Biomechanics. Researcher of the Biomechanics and Functional Morphology Laboratory, Interdisciplinary Centre for the Study of Human Performance (CIPER), Faculty of Human Kinetics, University of Lisbon, and member of the International Martial Arts and Combat Sports Scientific Society (IMACSSS). His research focuses are on biomechanics and motor behavior, focusing on special populations and sport performance. He has the 3rd Dan in Wado-Ryu Karate and is a certified coach by the Federation of Karate Portugal (FNKP). E-mail: marcobranco@esdrm.ipsantarem.pt

António M. VencesBrito (Portugal) Bsc in Radiology from the School of Technology of the Health from Lisbon; Bsc in Sport Sciences; MSc in High Performance Training and the PhD in Human Motricity, from the Faculty of Human Kinetics, Technical University of Lisbon, Portugal and Specialist in Karate Coaches Formation, from IPSantarém. Professor - Lecturer in Anatomophysiology; coordinator and tutor of Combat Sports and Martial Arts formation in the Sports Sciences School of Rio Maior, Polytechnic Institute of Santarém, Portugal. Research on kinesiology; neuromuscular activity and control; sport physiology and traumatology. Researcher of the Life Quality Research Center (CIEQV) and a member of the Research Unit of the Polytechnic Institute of Santarém (UIIPS). Board member of the International Martial Arts and Combat Sports Scientific Society where he is co-responsible for the division of kinesiology. Shotokan karate practitioner since 1975. Karate coach formatter of the Portuguese Karate Federation (FNK-P). Member of the Idokan Poland Association - Karate division. E-mail: abrito@esdrm.ipsantarem.pt

Ana Paula Seabra (Portugal). MSc in Motor Development. Assistant, Department of Movement Sciences (Polytechnic Institute of Santarém). Researcher in Physical Growth, Maturation and Motor Development. Member of Applied Psychology- Research Unity of the Polytechnic Institute of Santarém (UI-IPS). E-mail: apseabra@esdrm.ipsantarem.pt 
Cristiana Mercê (Portugal). Invited Professor at ESDRM-IPS, Sport Sciences School of Rio Maior - Polytechnic Institute of Santarém (Movement Sciences Department); Researcher at Life Quality Research Centre and at Unit-Polytechnic Institute of Santarém (Motor Behavior - Member); PhD Student in Human Kinetics, Speciality Motor Behavior; Master of Physical Activity for Special Populations. E-mail: cristianamerce@esdrm.ipsantarem.pt

Mário A. Rodrigues-Ferreira (Portugal). PhD in Sport Sciences. Invited Associate Professor at the Sport Sciences School of Rio Maior, Polytechnic Institute of Santarém. Researcher of the Life Quality Research Center (CIEQV) and a member of the Research Unit of the Polytechnic Institute of Santarém (UIIPS). Research topics: motor control and learning, neuromuscular function and sport physiology. E-mail: marioarferreira@esdrm.ipsantarem.pt

Vítor Milheiro (Portugal) is Adjunct Professor in Sport Sciences School of Rio Maior - Polytechnic Institute of Santarém, MSc in Sport Sciences, specialization in athletics and cycling biomechanics, member of the Polytechnic Institute of Santarém Research Unity. E-mail: vmilheiro@esdrm.ipsantarem.pt

David Catela (Portugal). MSc in Motor Development; PhD in Human Motricity. Assistant Professor, Head of Department of Movement Sciences (Polytechnic Institute of Santarém). Researcher in Motor Development, Motor Learning and Motor Control. Head of Applied Psychology- Research Unity of the Polytechnic Institute of Santarém (UI-IPS). Quality of Life Research Centre (CIEQV) Member. E-mail: catela@esdrm.ipsantarem.pt 